Date Issued: January 14, 1964

Report Number $Y-1454$

Systems for Nuclear

(4)

Auxiliary Power (SNAP)

UNION CARBIDE CORPORATION

Nuclear Division

$$
\text { Y-12 PLANT }
$$

Contract W-7405-eng-26

With the US Atomic Energy Commission

\title{
SHIELDING STUDIES: NEUTRON IRRADIATION DAMAGE \\ TO A LITHIUM HYDRIDE COMPACT
}

C. W. Hamill

F. B. Waldrop

- NOTICE- account of work This report was prepared as an account of weither sponsored by the United States Gover States Energy the United States nor the United Station, nor any of Research and Development Administration, contractors, their employees, nor any of their makes any subcontractors, or their enployees, maks any wabcontry, express or implied, or assumes any legal wablity or responsibility for the accuracy, completenes labilty or resp any information, apparatus, product or or usefulness of any informents that its use would not

process disclosed, or represents

Classification cancelled to by authority of

by

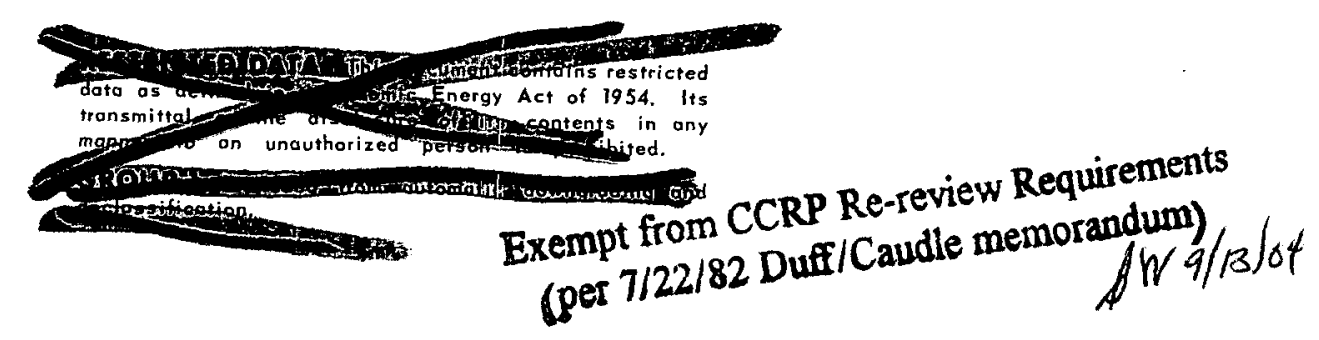

DISTRIBUTION OE THIS DOCUMENT WS UNLIMITED Oak Ridge, Tennessee November 11, 1963 


\section{DISCLAIMER}

This report was prepared as an account of work sponsored by an agency of the United States Government. Neither the United States Government nor any agency Thereof, nor any of their employees, makes any warranty, express or implied, or assumes any legal liability or responsibility for the accuracy, completeness, or usefulness of any information, apparatus, product, or process disclosed, or represents that its use would not infringe privately owned rights. Reference herein to any specific commercial product, process, or service by trade name, trademark, manufacturer, or otherwise does not necessarily constitute or imply its endorsement, recommendation, or favoring by the United States Government or any agency thereof. The views and opinions of authors expressed herein do not necessarily state or reflect those of the United States Government or any agency thereof. 


\section{DISCLAIMER}

Portions of this document may be illegible in electronic image products. Images are produced from the best available original document. 
Report Number Y-1454

Systems for Nuclear

Auxiliary Power (SNAP)

Distribution:

Anderson, K. E. (AEC-Washington)

Asquith, J.G. (Atomics International)

Bailey, E. W.

Ballenger, H. F.

Bell, B. B.

Bernander, N.K.

Blizard, E. P.

(ORNL)

Bradburn, J., Jr. (Lockheed-Marietta)

Burkhart, L. E.

Clifford, C. E.

Dow, Neal

Ebert, J.W.

Ekern, W. F. (Lockheed-Sunnyvale)

Evans, G. W.

Fortenbery, M. J.

Googin, J. M.

Greenfield, H. H. (Lockheed-Sunnyvale)

Hamill, C. W.

Heckert, W. E.

Hemphill, L. F.

Hopkins, C. C.

Huber, A.P.

(ORGDP)

Jackson, V.C.

In addition, this report is distributed in accordance with the category, Systems for Nuclear Auxiliary Power (SNAP) as given in the "USAEC Standard Distribution Lists for Classified Scientific and Technical Reports", M-3679 (31st Edition), September 15, 1963. 
Keller, C. A.

King, E. M.

Kite, H. T.

Lafleur, J. D., Jr.

Lewis, F. $O$.

Lockhart, G. B.

MacPherson, H. G.

McLendon, J. D.

Miller, A. J.

Mitchel, G.W.

Murray, J. P.

Patton, F. S.

Rader, D. H.

Schwenn, M. F.

Stoner, $\mathrm{H}$. H.

Tench, F. M.

Tierney, J. J.

Waldrop, F. B.

Waters, J. L.

Welch, F. H.

Whitson, W. K.

Wilkinson, P. E.

Winkel, R. A.

Zurcher, E.

$Y-12$ Central Files

$Y-12$ Central Files
(AEC-ORO)(4)

(ORNL)

(AEC-Washington)

(ORGDP)

(ORNL)

(ORNL)

(ORGDP)

(General Dynamics-Fort Worth)

(Atomics International)

(Paducah)

(5)

$(\mathrm{Y}-12 \mathrm{RC})$ 
A sample of lithium hydride was prepared at $Y-12$ for irradiation at the General Dynamics-Convair facility in Fort Worth. After exposure to $1.6 \times 10^{17} \mathrm{n} / \mathrm{cm}^{2}$ for 44 hours and 40 minutes, the specimen was returned to Oak Ridge for examination. Results indicate some swelling, but not enough to cause concern in the presently proposed SNAP shields. 


\section{CONTENTS}

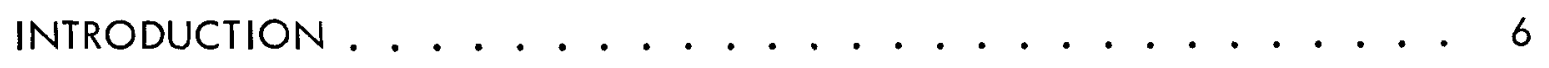

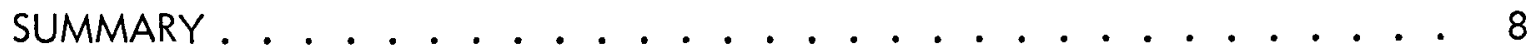

INVESTIGATION OF THE PROBLEM. ................

Fabrication and Test Procedure ................ 9

Tests and Discussion of Results. . . . . . . . . . . . . . . 10

REFERENCES ................... 17

ACKNOWLEDGEMENTS ................... 18 
For some satellite applications it is planned to use lithium hydride as a neutron shield between a nuclear power reactor (SNAP) and the electronics package. Previous work had indicated that radiation damage to lithium hydride compacts would not be a problem under the proposed operating conditions of space reactors.

Some years ago it was planned to use $\mathrm{LiH}$ as the neutron shield around the General Electric Aircraft Reactor. (1) As a consequence a considerable number of radiation damage tests were run with several small samples. It appeared from these tests that at the planned operating temperature and neutron dosage of the aircraft reactor the physical integrity of the blocks of hydride would be maintained. However, no large-scale tests were run and no data were obtained on the rate or extent of pressure rise in a sealed container under irradiation, or on changes in the physical dimensions.

In 1962, a preliminary test was run to determine how efficiently the proposed thickness of lithium hydride would protect an electronics package. The test shield was simply an aluminum can filled with blocks of lithium hydride andbore no resemblance to the geometry of the actual shield. Early in the irradiation test (carried out at the General Dynamics-Convair facility in Fort Worth (NARF) for Lockheed Aircraft, Sunnyvale, California) the can ruptured. The lithium hydride blocks were removed and recanned but trouble was still experienced, caused by an apparent rapid dimensional growth of the blocks. (2)

This experience caused considerable misgivings in some quarters regarding the entire concept of a lithium hydride shield. In an effort to ascertain the cause of the observed difficulties, two of the irradiated blocks were sent to $Y-12$ for examination. Measurements of the dimensions of these blocks indicated a significant growth, and their strengths were so low that the blocks would hardly hold together under ordinary handling.

Chemical analyses of samples taken from the irradiatedblocks showed them to have a very high lithium hydroxide content $(\sim 11.2 \%)$ indicating a gross exposure to atmospheric moisture. This exposure probably occurred during the time the powder was handled incidental to pressing it into blocks, and in handling the blocks themselves. Information indicated that low-humidity areas were not available to the supplier for either of these operations. If there was a significant exposure of the lithium hydride powder to atmospheric mositure before being compacted into blocks, the powder particles would each be coated with a rather thick layer of lithium hydroxide. Then, the temperature rise in the blocks during irradiation would cause the following reaction to proceed at a rapid rate:

$$
\mathrm{LiOH}+\mathrm{LiH} \rightarrow \mathrm{Li}_{2} \mathrm{O}+\mathrm{H}_{2} \cdot
$$


The effects of this reaction could be twofold: (1) the change in crystal structure on conversion of the bonding layer from lithium hydroxide to lithium oxide could result in a drastic decrease in bond strength, and (2) the rate of hydrogen evolution resulting from a rapid internal heating of the compacts could be so high that the hydrogen could not escape from the site at which it was generated until a pressure developed high enough to rupture the bond. The appearance of the compact indicated that some such mechanism of disintegration took place because the material which had spalled was reduced to what seemed to be grains much like those from which the compact might have been pressed.

The observed growth in the dimensions of the block can readily be attributed to intergranular effects such as those just described. In addition, there was probably some dimensional growth due to an enlargement of the crystal lattice. This is a common effect of radiation and has been observed in lithium fluoride. (3)

It was indicated that some testing should be done on a larger scale than that previously used by the GEANP. $Y-12$ was interested because several SNAP reactor shields have been fabricated here, although the lithium hydride blocks used in the test at Convair had been supplied by a commercial source. 
In conjunction with plans to use lithium hydride as a neutron shield in the SNAP reactor program, a $Y$-12-fabricated cylinder of lithium hydride was irradiated at General Dynamics-Convair. Post-irradiation examination of the cylinder revealed that the physical integrity of the salt survived a neutron dosage of $1.6 \times 1017 \mathrm{n} / \mathrm{cm}^{2}$ over a time period of 44 hours and 40 minutes. 


\section{INVESTIGATION OF THE PROBLEM}

\section{FABRICATION AND TEST PROCEDURE}

A 6-inch-diameter cylinder, 6 inches in length, was fabricated from virgin normal lithium hydride containing a perforated stainless steel honeycomb just as was used in the SNAP reactor shields fabricated for Atomics International. The compact from which the cylinder was machined was isostatically pressed at 30,000 psi and subsequently sintered at $1100^{\circ} \mathrm{F}$. Machining operations were performed under superdry conditions ( $35 \mathrm{ppm}$ water vapor).

The mach ined cylinder (also under superdry conditions) was sealed in a Type 304 stainless steel container ("can") having a wall thickness of 0.060 inch, then given a hydrogen outgassing test. After outgassing, a pressure transducer was installed on the can and the can pressurized to approximately 3 psia with helium. An integrated leak rate of $7 \times 10^{-6} \mathrm{cc} / \mathrm{sec}$ was obtained on the completed assembly prior to shipment to General Dynamics-Fort Worth where the specimen was to be irradiated.

The LiH test assembly was irradiated for a period of 44 hours and 40 minutes. (4) After irradiation, the assembly was returned for disassembly and evaluation. 


\section{TESTS AND DISCUSSION OF RESULTS}

Laboratory analyses showed that the powder from which the specimen was pressed at $Y-12$ had a combined lithium and hydrogen content of $99.5 \mathrm{wt} \%$. Outgassing data indicated that, prior to outgassing, the test piece had a hydrogen outgassing potential of $14.7 \mathrm{cc}$. After outgassing at $275^{\circ} \mathrm{F}$ for 63 hours, the residual outgassing potential was calculated to be $3.7 \mathrm{cc}$. A laboratory analysis of a specimen taken from the irradiated test piece showed it to contain 83.64 wt $\% \mathrm{Li}$ and $11.41 \mathrm{wt} \% \mathrm{H}$. These results are undoubtedly biased somewhat due to the fact that the specimen was exposed to the wet atmosphere of the hot cell.

At NARF, the assembly was irradiated for a period of 44 hours and 40 minutes, and at a GTR power level of $3 \mathrm{mw}$ with the longitudinal axis of the can perpendicular to the reactor face. This run resulted in an integrated neutron flux of $1.6 \times 10^{17} \mathrm{n} / \mathrm{cm}^{2}$ $(E=7.1 \mathrm{Mev}) .(4)$

Table 1 contains the pressure and temperature data as recorded during irradiation. The temperature was monitored by three Chromel-Alumel thermocouples and the pressure by a 0 - 15 psia resistance-type transducer real by a volt-ohm meter. The thermocouples were related to positions in the assembly in accordance with the sketch at the bottom of Table 1 (Points 1, 2, and 3). The resistance measurements on the pressure transducer after approximately five hours of irradiation indicated a variation in the transducer characteristics. The resistances recorded between the wiper and each end terminal did not always equal the total resistance between end terminals as it had initially. This discrepancy resulted in differences in pressure as determined from Readings $A-B$ and $B-C$.

After 44 hours and 40 minutes it became necessary to interrupt the irradiations for rate-effect investigations on another item of equipment in the test. The cooling air flow was shut off to lower the cooling rate as the reactor was retracted. The temperature and pressure of the subject assembly began to diminish initally, but at approximately 45 minutes after retraction a marked rise in pressure was observed. The pressure continued to rise gradually toward atmospheric and it was decided to remove the assembly from the radiation field. During pressure monitoring at the end of the experiment, intermittent open-circuit conditions were observed on the transducer. The cause of the variations is not known since exclmination of the unit was not attempted. Within two hours after observing loss of can seal, the assembly was wrapped in polyethylene sheet with several bags of dessicant and shipped to the ORNL.

Upon receipt of the assembly at the ORNL, it was placed in a hot cell for disassembly and evaluation. Pressure in the can was measured with the pressure transducer on the can and with a Bourdon-tube gage. Both indicated atmospheric pressure. After measuring the pressure in the can, the gas was sampled and found to be air. 
Table 1

PRESSURE AND TEMPERATURE DATA RECORDED DURING IRRADIATION (General Dynamics NARF Facility)

\begin{tabular}{|c|c|c|c|c|c|c|c|c|c|c|}
\hline Date & Time & $\begin{array}{c}\mathrm{TC}{ }^{(1)} \\
(\mathrm{OF})\end{array}$ & $\begin{array}{l}\text { TC } 2 \\
\left({ }^{\circ} \mathrm{F}\right)\end{array}$ & $\begin{array}{l}\text { TC } 3 \\
\text { (OF) }\end{array}$ & $\begin{array}{c}R_{1} \\
A-B \\
\text { (ohms) }\end{array}$ & $\begin{array}{c}R_{2} \\
C-B \\
\text { (ohms) }\end{array}$ & $\begin{array}{c}R_{3} \\
A-C \\
\text { (ohms) }\end{array}$ & $\begin{array}{c}\text { Pressure } \\
\text { A-B } \\
\text { (psia) }\end{array}$ & $\begin{array}{c}\text { Pressure } \\
\text { C-B } \\
\text { (psia) }\end{array}$ & $\begin{aligned} n & >0.1 \text { Mev } \\
& \times 10^{-15}\end{aligned}$ \\
\hline $4-16-63$ & $17: 51$ & 85 & 85 & 85 & 675 & 1425 & 2100 & 5.8 & 5.8 & 0.0 \\
\hline $4-16-63$ & $18: 10$ & & at & 3 Mego & atts & & & & & \\
\hline $4-16-63$ & $18: 15$ & 125 & 105 & 105 & 700 & 1400 & 2100 & 6.0 & 6.0 & \\
\hline $4-16-63$ & $18: 30$ & 205 & 180 & 165 & 760 & 1340 & 2100 & 6.6 & 6.6 & 1.2 \\
\hline $4-16-63$ & $18: 50$ & 230 & 207 & 180 & 775 & 1325 & 2100 & 6.8 & 6.8 & \\
\hline $4-16-63$ & $19: 00$ & 245 & 227 & 194 & 780 & 1320 & 2100 & 6.8 & 6.8 & \\
\hline $4-16-63$ & $19: 15$ & 262 & 250 & 205 & 800 & 1300 & 2100 & 7.0 & 7.0 & \\
\hline $4-16-63$ & $19: 30$ & 275 & 267 & 220 & 825 & 1275 & 2100 & 7.2 & 7.2 & \\
\hline $4-16-63$ & $19: 48$ & 292 & 287 & 232 & 850 & 1250 & 2100 & 7.5 & 7.5 & \\
\hline $4-16-63$ & $20: 00$ & 302 & 300 & 242 & 875 & 1225 & 2100 & 7.7 & 7.7 & \\
\hline $4-16-63$ & $20: 15$ & 308 & 306 & 247 & 875 & 1225 & 2100 & 7.7 & 7.7 & \\
\hline $4-16-63$ & $20: 30$ & 312 & 312 & 250 & 900 & 1200 & 2100 & 8.0 & 8.0 & 8.4 \\
\hline $4-16-63$ & $21: 00$ & 313 & 335 & 250 & 900 & 1200 & 2100 & 8.0 & 8.0 & \\
\hline $4-16-63$ & $21: 40$ & 325 & 325 & 262 & 900 & 1200 & 2100 & 8.0 & 8.0 & \\
\hline $4-16-63$ & 22: 18 & 327 & 330 & 264 & 900 & 1200 & 2100 & 8.0 & 8.0 & \\
\hline $4-16-63$ & $22: 30$ & 327 & 330 & 264 & 900 & 1200 & 2100 & 8.0 & 8.0 & 14.7 \\
\hline $4-16-63$ & $23: 15$ & 327 & 330 & 265 & 900 & 1200 & 2100 & 8.0 & 8.0 & \\
\hline $4-17-63$ & $00: 26$ & 330 & 330 & 265 & 975 & 1200 & 2100 & 8.7 & 8.0 & 21.6 \\
\hline $4-17-63$ & $01: 30$ & 332 & 332 & 265 & 975 & 1200 & 2175 & 8.7 & 8.0 & \\
\hline $4-17-63$ & $02: 30$ & 335 & 335 & 265 & 975 & 1200 & 2175 & 8.7 & 8.0 & 29.1 \\
\hline $4-17-63$ & $03: 42$ & 335 & 335 & 272 & 1000 & 1180 & 2180 & 9.0 & 8.2 & \\
\hline $4-17-63$ & $05: 15$ & 325 & 325 & 260 & 1000 & 1175 & 2175 & 9.0 & 8.3 & \\
\hline $4-17-63$ & $05: 40$ & 325 & 325 & 260 & 960 & 1130 & 2100 & 8.6 & 8.7 & \\
\hline $4-17-63$ & $06: 28$ & 325 & 325 & 260 & 960 & 1130 & 2100 & 8.6 & 8.7 & \\
\hline $4-17-63$ & $07: 35$ & 322 & 322 & 260 & 970 & 1120 & 2100 & 8.7 & 8.8 & \\
\hline $4-17-63$ & 08:33 & 318 & 320 & 258 & 980 & 1120 & 2080 & 8.8 & 8.8 & \\
\hline $4-17-63$ & $09: 35$ & 318 & 318 & 258 & 980 & 1120 & 2100 & 8.8 & 8.8 & \\
\hline $4-17-63$ & $10: 32$ & 318 & 318 & 257 & 1000 & 1100 & 2100 & 9.0 & 9.0 & \\
\hline $4-17-63$ & $11: 29$ & 318 & 318 & 258 & 1000 & 1100 & 2100 & 9.0 & 9.0 & \\
\hline $4-17-63$ & $12: 30$ & 320 & 319 & 260 & 1020 & 1100 & 2100 & 9.2 & 9.0 & 65.1 \\
\hline $4-17-63$ & $13: 30$ & 322 & 320 & 262 & 1100 & 1200 & 2100 & 10.0 & 8.0 & \\
\hline $4-17-63$ & $14: 30$ & 344 & 323 & 265 & 1100 & 1100 & 2100 & 10.0 & 9.0 & \\
\hline $4-17-63$ & $16: 30$ & 322 & 320 & 265 & 1100 & 1100 & 2100 & 10.0 & 9.0 & \\
\hline $4-17-63$ & $17: 30$ & 317 & 317 & 260 & 1100 & 1100 & 2100 & 10.0 & 9.0 & \\
\hline $4-17-63$ & $18: 30$ & 316 & 315 & 259 & 1100 & 1075 & 2100 & 10.0 & 9.3 & \\
\hline $4-17-63$ & 19:30 & 320 & 320 & 264 & 1100 & 1050 & 2100 & 10.0 & 9.5 & \\
\hline $4-17-63$ & $20: 30$ & 320 & 320 & 263 & 1100 & 1050 & 2100 & 10.0 & 9.5 & \\
\hline $4-17-63$ & $21: 30$ & 320 & 318 & 263 & 1125 & 1050 & 2100 & 10.2 & 9.5 & \\
\hline $4-17-63$ & $22: 30$ & 319 & 317 & 262 & 1125 & 1040 & 2100 & 10.2 & 9.6 & 101.1 \\
\hline $4-17-63$ & $23: 30$ & 320 & 315 & 260 & 1140 & 1030 & 2100 & 10.4 & 9.7 & \\
\hline $4-18-63$ & $00: 30$ & 320 & 317 & 262 & 1140 & 1025 & 2100 & 10.4 & 9.7 & 108.3 \\
\hline $4-18-63$ & $01: 55$ & 320 & 320 & 267 & 1175 & 1025 & 2125 & 10.8 & 9.8 & \\
\hline $4-18-63$ & $04: 15$ & 315 & 311 & 267 & 1175 & 1000 & 2150 & 10.8 & 9.8 & \\
\hline $4-18-63$ & $06: 10$ & 315 & 311 & 267 & 1175 & 975 & 2150 & 10.8 & 10.2 & \\
\hline $4-18-63$ & $07: 00$ & 315 & 310 & 267 & 1200 & 975 & 2150 & 11.0 & 10.2 & \\
\hline $4-18-63$ & $07: 36$ & 312 & 308 & 267 & 1200 & 975 & 2150 & 11.0 & 10.2 & \\
\hline $4-18-63$ & $08: 39$ & 312 & 308 & 267 & 1200 & 975 & 2150 & 11.0 & 10.2 & \\
\hline $4-18-63$ & $09: 30$ & 308 & 303 & 265 & 1230 & 975 & 2150 & 11.3 & 10.2 & \\
\hline $4-18-63$ & $10: 34$ & 312 & 307 & 258 & 1250 & 950 & 2150 & 11.5 & 10.5 & 144.2 \\
\hline $4-18-63$ & $11: 39$ & 313 & 308 & 259 & 1250 & 970 & 2150 & 11.5 & 10.3 & \\
\hline $4-18-63$ & $12: 38$ & 313 & 307 & 260 & 1250 & 975 & 2150 & 11.5 & 10.2 & \\
\hline $4-18-63$ & $13: 30$ & 310 & 303 & 255 & 1250 & 925 & 2100 & 11.5 & 10.7 & \\
\hline $4-18-63$ & $14: 34$ & 310 & 302 & 255 & 1250 & 925 & 2100 & 11.5 & 10.7 & 158.6 \\
\hline $4-18-63$ & $14: 50$ & \multicolumn{4}{|c|}{ Retracted } & & & & & 160 \\
\hline $4-18-63$ & $15: 05$ & 250 & 275 & 250 & 1225 & 950 & 2125 & 11.3 & 10.5 & \\
\hline $4-18-63$ & $15: 20$ & 220 & 250 & 232 & 1200 & 975 & 2125 & 11.0 & 10.3 & \\
\hline $4-18-63$ & $15: 36$ & 200 & 225 & 217 & 1450 & 700 & - & 13.5 & 12.8 & \\
\hline
\end{tabular}


Table 1 (Continued)

PRESSURE AND TEMPERATURE DATA RECORDED DURING IRRADIATION (General Dynamics NARF Facility)

\begin{tabular}{|c|c|c|c|c|c|c|c|c|c|c|}
\hline Date & Time & $\begin{array}{c}\text { TC } 1(1) \\
\text { (OF) }\end{array}$ & $\begin{array}{c}\mathrm{TC} 2 \\
\text { (OF) }\end{array}$ & $\begin{array}{r}T C 3 \\
(\mathrm{OF}) \\
\end{array}$ & $\begin{array}{c}R_{1} \\
A-B \\
\text { (ohms) }\end{array}$ & $\begin{array}{c}R_{2} \\
C-B \\
\text { (ohms) }\end{array}$ & $\begin{array}{c}R_{3} \\
A-C \\
\text { (ohms) }\end{array}$ & $\begin{array}{c}\text { Pressure } \\
\text { A-B } \\
\text { (psia) }\end{array}$ & $\begin{array}{c}\text { Pressure } \\
C-B \\
\text { (psia) }\end{array}$ & $\begin{array}{c}n>0.1 \mathrm{Mev} \\
\times 10^{-15} \\
\end{array}$ \\
\hline $\begin{array}{l}4-18-63 \\
4-18-63 \\
4-24-63\end{array}$ & $\begin{array}{l}15: 52 \\
16: 43 \\
10: 00\end{array}$ & $\begin{array}{l}190 \\
132\end{array}$ & $\begin{array}{l}215 \\
162\end{array}$ & $\begin{array}{l}205 \\
100\end{array}$ & $\begin{array}{c}1500 \\
- \\
1500\end{array}$ & $\begin{array}{l}650 \\
- \\
500\end{array}$ & $\begin{array}{c}2100 \\
- \\
2050\end{array}$ & $\begin{array}{c}14.0 \\
- \\
14.0\end{array}$ & $\begin{array}{c}13.5 \\
- \\
15.0\end{array}$ & \\
\hline & & & $\overline{\mathrm{Di}}$ & $\begin{array}{l}\text { ion of } \\
\text { Air } \mathrm{Fl}\end{array}$ & ling & & 1 & & & \\
\hline
\end{tabular}

Readings taken by evacuating the can and allowing it to pressurize through the leak showed the can to have a large leak rate, undoubtedly in the pressure transducer. These readings are given in Table 2 .

Table 2

READINGS TAKEN ON EVACUATED CAN WITH LEAK EXPOSED TO ATMOSPHERIC PRESSURE

\begin{tabular}{ccc}
\hline $\begin{array}{c}\text { Can Pressure } \\
\text { (inches) }\end{array}$ & $\begin{array}{c}\text { Time Elapsed } \\
\text { (min) }\end{array}$ & $\begin{array}{c}\text { Rote at STP } \\
\text { (cc/min) }\end{array}$ \\
\hline-21.1 & 0 & - \\
-19.0 & 5 & 7.05 \\
-15.0 & 15 & 3.51 \\
-10.0 & 32 & 3.11 \\
-1.2 & 100 & 1.27 \\
\hline
\end{tabular}

Resistance readings taken on the three thermocouples showed the continuity of all three to be good. Each thermocouple gave a reading of 1.42 millivolts, or $35.5^{\circ} \mathrm{C}$ in a $30^{\circ} \mathrm{C}$ atmosphere as read by a thermometer.

After completion of externally made evaluations, the can was opened and the salt specimen removed. The specimen was black throughout, as is typical of irradiated $\mathrm{LiH}$, but the specimen and container were in excellent condition. No cracking, spalling, or disintegration of the salt specimen was noted, nor was there any visible corrosion of the stainless steel container. Pencil marks made on the salt part to indicate points at which measurements were made prior to assembly were still clearly legible. Pictures made of the container and salt at various stages of disassembly are shown in Figures 1 through 6.

Prior to irradiation, four measurements each on the diameter and length of the salt specimen were made at equally spaced intervals. After irradiation, these measurements were retaken at precisely the same points. Both sets of measurements showed 


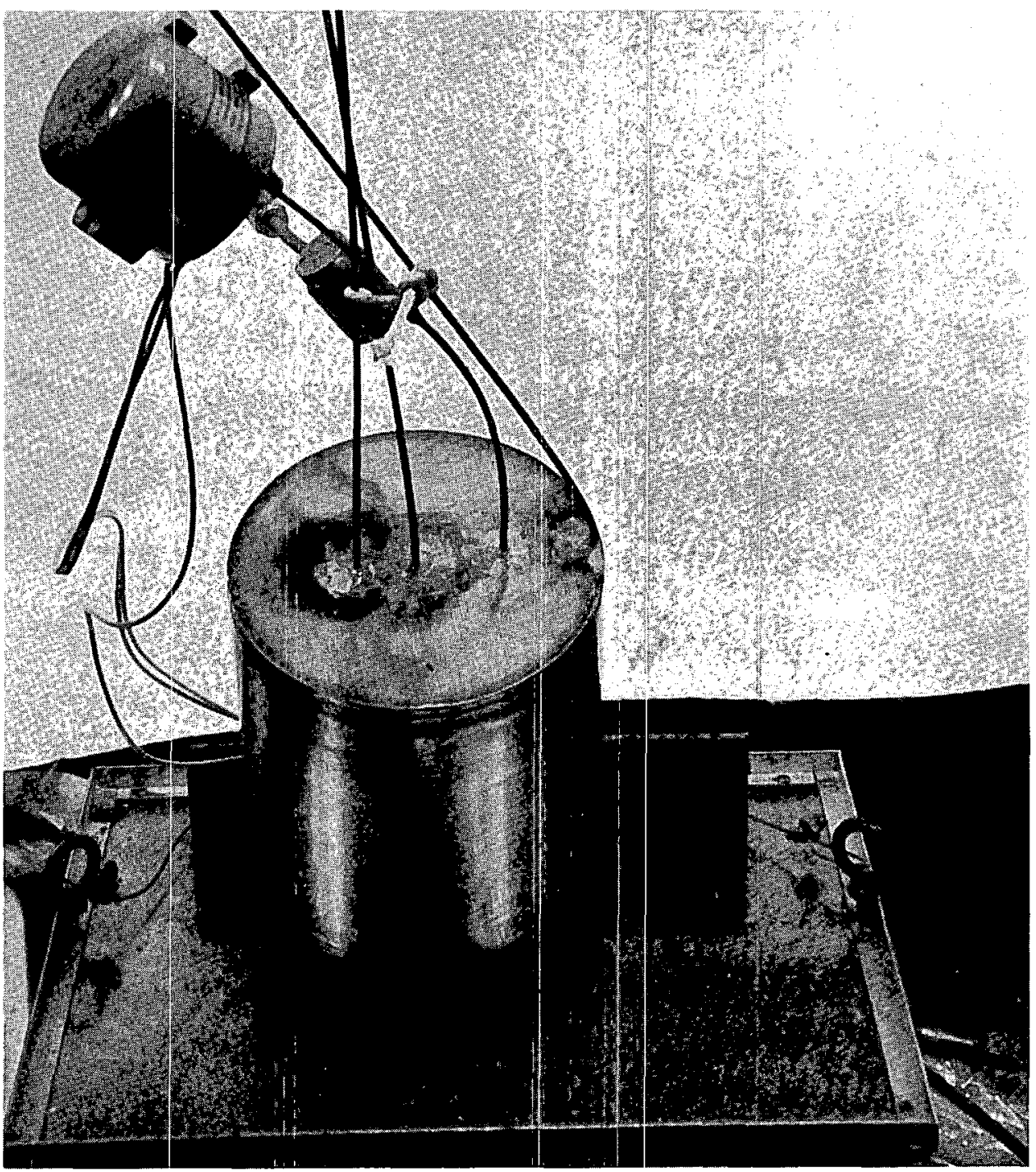

HCO-1912(U)

Figure 1. OUTSIDE OF IRRADIATION TEST PIECE ASSEMBLY. (External Arrangement of the Three Thermocouples and the Pressure Transducer is Shown)

that the part grew most $(2.4 \%)$ on the diameter of the end toward the radiation source. The length grew an average of $1.4 \%$. The measurements are reported in Table 3 .

In conjunction with growth determinations, $X$-ray diffraction studies were made on specimens taken from a normal, unirradiated $\mathrm{LiH}$ compact and on specimens taken from the irradiated test piece. The $A$ spacing on the unirradiated specimen was found to be 4.0833 angstroms while that of the irradiated specimens was 4.0837 angstroms. This difference represents a volume increase of $0.03 \%$ in the crystal lattice structure.

These results would seem to confirm the postulate that most of the radiation damage to the Convair shield blocks was due to intergranular effects and resulted from the 

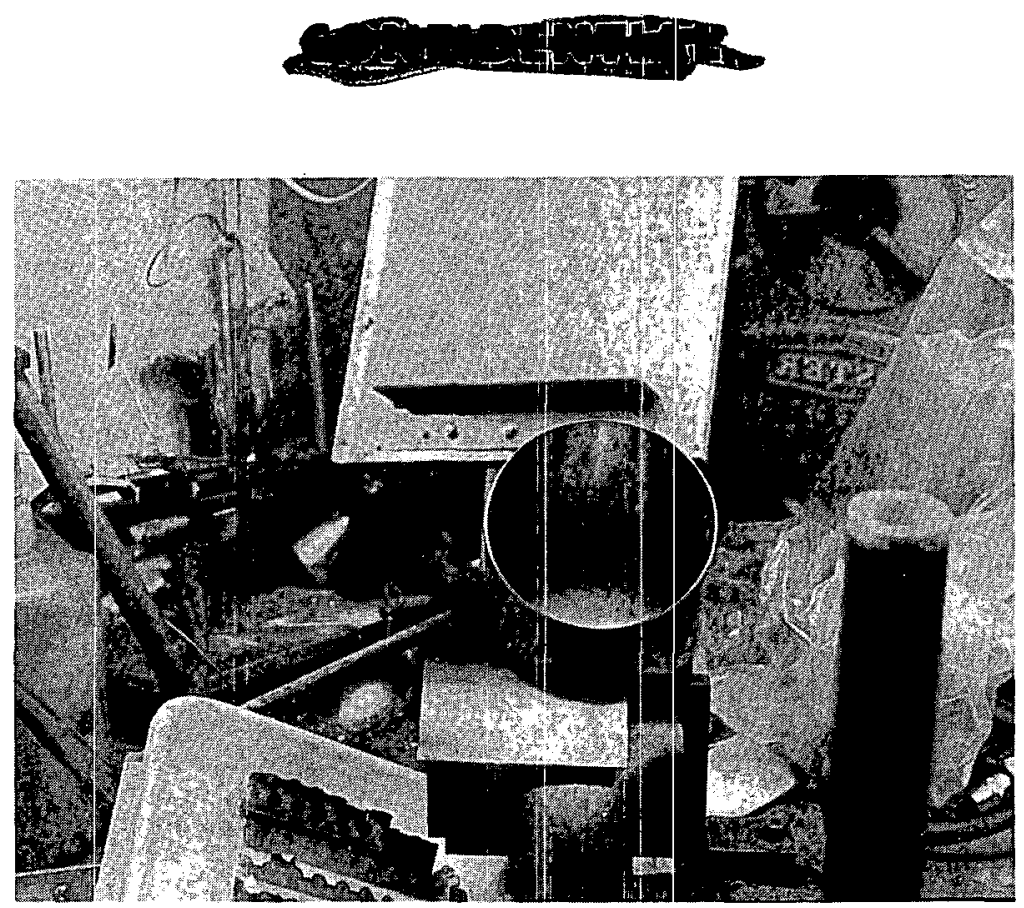

$\mathrm{HCO}-1931(U)$

Figure 2. INTERIOR OF THE SALT CONTAINER. (Note the Absence of any Corrosion)

lithium hydride powder having been excessively exposed to atmospheric moisture before compacting. There appears also to be a small growth in lattice spacing as a result of radiation which can be expected to cause some dimensional growth at the temperature at which this test was conducted.

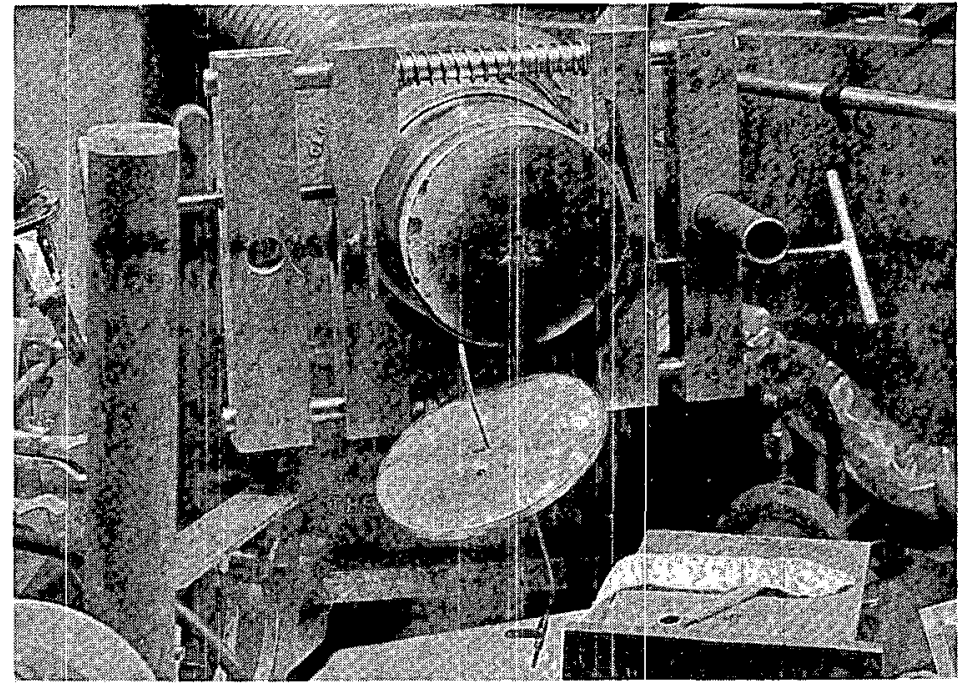

$\mathrm{HCO}-1916(\mathrm{U})$

Figure 3. END VIEW OF THE SALT PARTIALLY REMOVED FROM THE CONTAINER. (Chips along the Edges Were Made by the Cutting Tool during Lid Removal. White Portions Are Due to Hydroxide Formation during Lid Removal. The Hot Cell did not have a Dry Atmosphere. Thin Lines across the Face are the Honeycomb Cells. This End Was Facing Away from the Reactor.) 


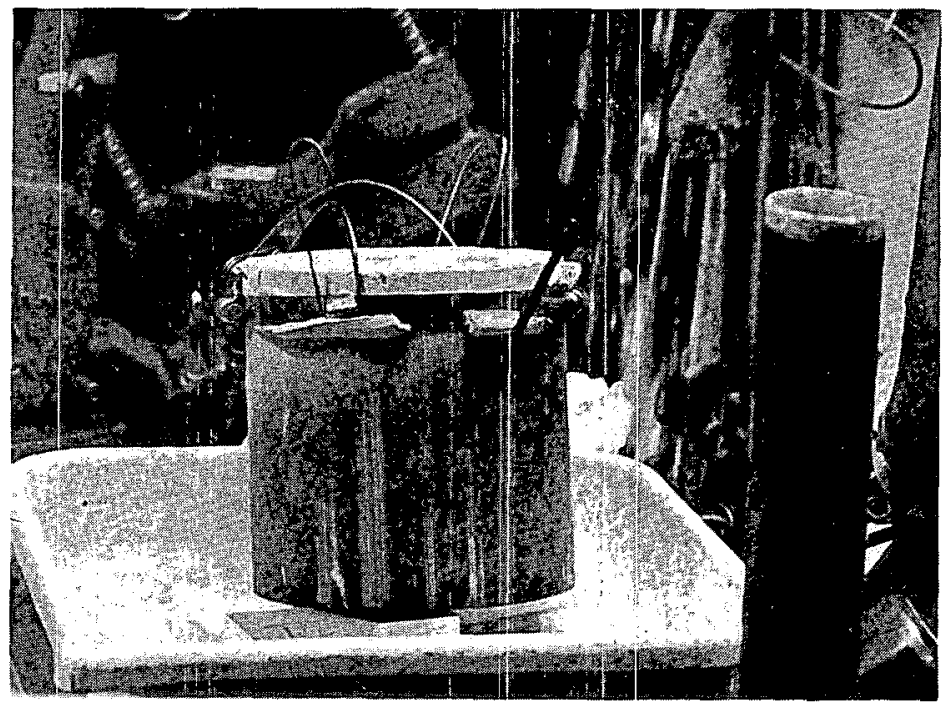

$\mathrm{HCO} \cdot 1917(\mathrm{U})$

Figisre 4. SIDE VIEW OF THE SALT SPECIMEN. (White Section at the Top is due to an Overnight Exposure to the Wet Atmosphere of the Hot Cell. Marks along the Side Were Made during the Extraction of the Salt from the Container.)

Growth effects, similar to those experienced in this test, can be removed by annealing LiF crystals at approximately $900^{\circ} \mathrm{F}$. (3) This temperature is believed to be associated with the point at which the crystal becomes electrically conductive. However, in view of the lower melting point of $\mathrm{LiH}$ and the fact that it is appreciably conductive at $800^{\circ} \mathrm{F}$, it is believed that growth effects under the proposed operating conditions of the SNAP shield will not pose a problem.

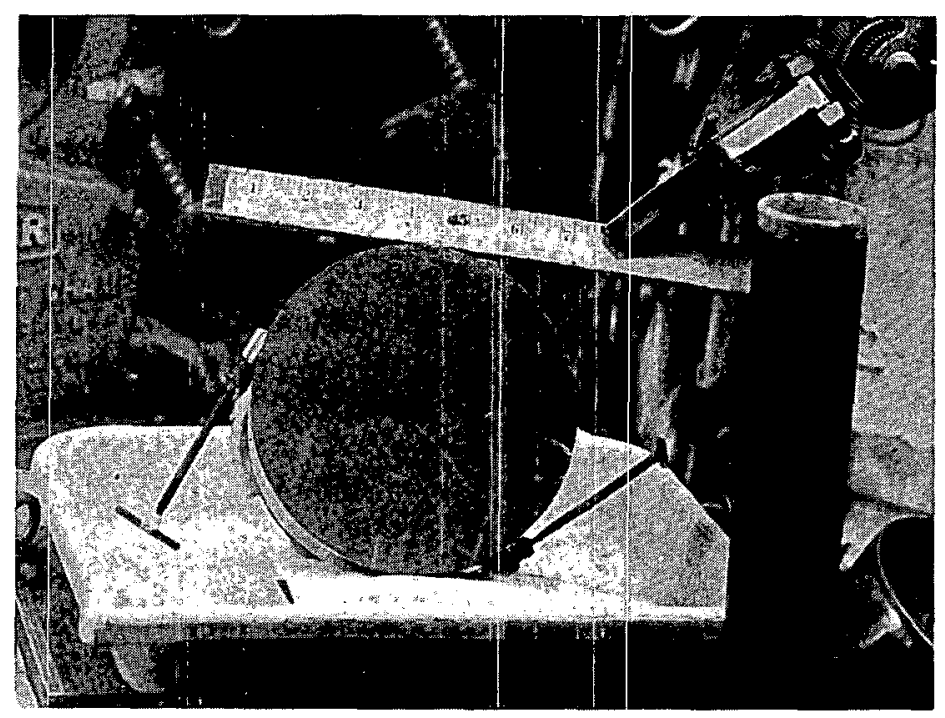

HCO-1920(U)

Figure 5. REACTOR END OF THE SALT SIPECIMEN. (Chipping along the Circumference of the Specimen Was Done during the Extraction of the Specimen from the Container.)

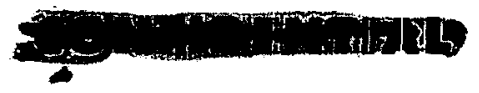



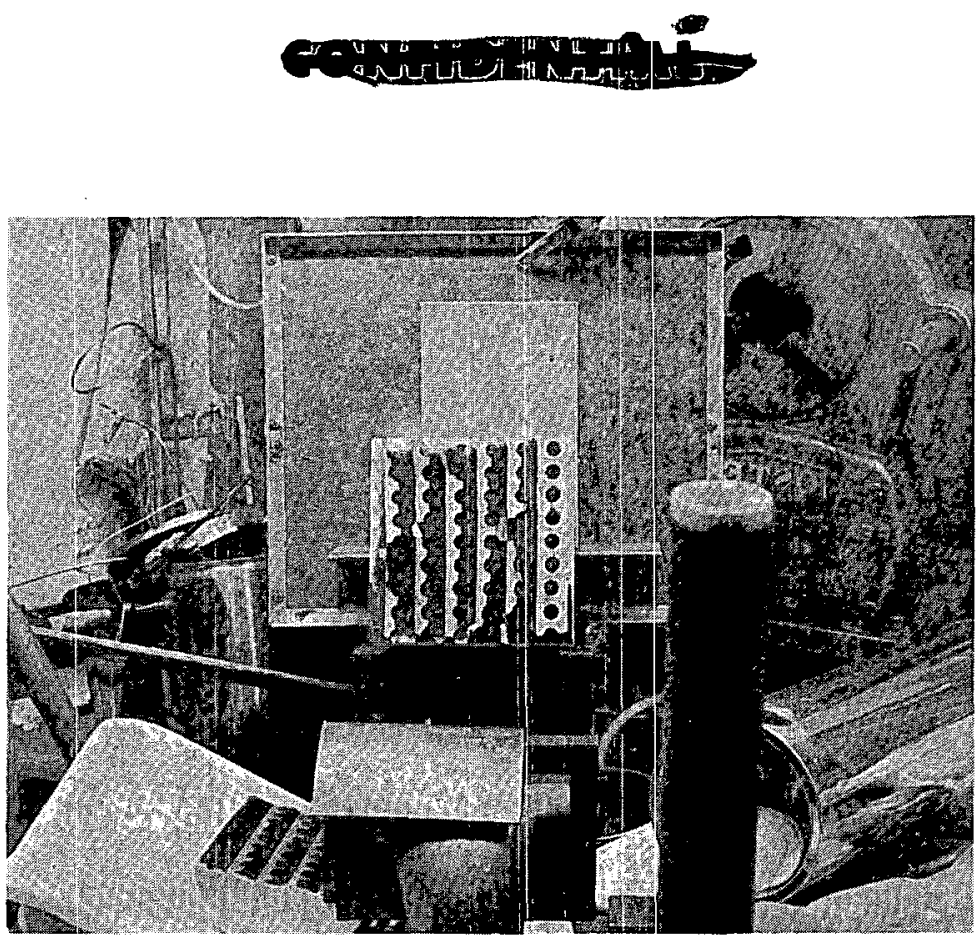

HCO-1932(U)

Figure 6. CROSS SECTION OF THE SALT SPECIMEN. (Honeycomb Cells Are Shown. Note the Black Coloring throughout the Part. This View Shows the Absence of Cracking.)

Table 3

MEASUREMENTS TAKEN ON SALT SPECIMEN BEFORE AND AFTER IRRADIATION

\begin{tabular}{ccccc}
\hline Point & $\begin{array}{c}\text { Preirradiation } \\
\text { Length } \\
\text { (inches) }\end{array}$ & $\begin{array}{c}\text { Post-Irradiation } \\
\text { Length } \\
\text { (inches) }\end{array}$ & $\begin{array}{c}\text { Preirradiation } \\
\text { Diameter (1) } \\
\text { (inches) }\end{array}$ & $\begin{array}{c}\text { Post-Irradiation } \\
\text { Diameter } \\
\text { (inches) }\end{array}$ \\
\hline 1 & 6.0028 & 6.0820 & 6.0060 & 6.0775 \\
2 & 6.0013 & 6.0878 & 6.0055 & 6.0910 \\
3 & 6.0023 & 6.0849 & 6.0060 & 6.1248 \\
4 & 6.0017 & 6.0784 & 6.0060 & $6.1493(2)$ \\
\hline
\end{tabular}

(1) Diameter measurements taken at two-inch intervals along the specimen.

(2) Source end.

To date, one compressive test has been made on a specimen that was 0.500 inch in diameter and 1.000-inch long and fabricated from irradiated salt. This specimen had a compressive strength of 18,000 psi. This value compares with a figure of $\sim 24,000$ psi for unirradiated sintered $\mathrm{LiH}$. 


\section{REFERENCES}

(1) Baxter, W. G. and Welch, F. H., "Apex-915 Shield Materials", Comprehensive Technical Report, General Electric Direct-Air-Cycle, 6DC-93A.

(2) Personal Communications between Messrs. H. Greenfield and W. F. Ekern of Lockheed Aircraft Corporation, Palo Alto, Californic and H. T. Kite and F. B. Waldrop of Union Carbide Corporation, Nuclear Division, Y-12 Plant, Oak Ridge, Tennessee.

(3) Senio, P. and Tucker, C. W., Jr., Radiation Effects in LiF, KAPL-1727, Knolls Atomic Power Laboratory, Schenectady, New York, June 25, 1957.

(4) Tierney, J. J., Letter of May I, 1963 to H. T. Kite, Y-12 Plant, Oak Ridge LiH Test Assembly, JJT:nih/28-2261/FW\#060-64, General Dynamics, Fort Worth, Texas. 


\section{ACKNOWLEDGEMENTS}

The authors are indebted to the $\mathrm{Y}-12$ production groups for assistance in the preparation of the specimen, to J. J. Tierney of General Dynamics for irradiation information, to E. M. King of the ORNL for hot cell operation, and to H. L. Yakel of the ORNL for determination of unit cell dimensions. 